Golden Gate University School of Law GGU Law Digital Commons

$12-1988$

\title{
Terrorism as an International Crime: Questions of Responsibility and Complicity
}

Sompong Sucharitkul

Golden Gate University School of Law, ssucharitkul@ggu.edu

Follow this and additional works at: http://digitalcommons.law.ggu.edu/pubs

Part of the International Law Commons

\section{Recommended Citation}

Sucharitkul, Sompong, "Terrorism as an International Crime: Questions of Responsibility and Complicity" (1988). Publications. Paper 528.

http://digitalcommons.law.ggu.edu/pubs/528

This Presentation is brought to you for free and open access by the Faculty Scholarship at GGU Law Digital Commons. It has been accepted for inclusion in Publications by an authorized administrator of GGU Law Digital Commons. For more information, please contact jfischer@ggu.edu. 
TERRORISM AS AN INTERNATIONAL CRIME

Questions of Responsibility and Complicity

BY PROFESSOR SOMPONG SUCHARITKUL *

Terrorism is a phenomenon in the contemporary world which occupies the attention of the international community. Terrorism as an international crime is readily more comprehensible and susceptible of clearer definition than sheer acts of terrorism by whomsoever performed.

This paper is confined to questions of responsibility and complicity in connection with terrorism as an international crime, whatever the definition is ultimately adopted of "terrorism," and whatever the meaning to be ascribed to an "international crime."

Taking the cue from Professor Yoram Dinstein, 1 some of the salient features and common elements present in the varying definition of terrorism as an international crime still permit a scientific and intelligible treatment of a number of questions relating to responsibility and complicity.

As terrorism is inter alia an offense against the peace and security of mankind according to the latest draft code undertaken by the International Law Commission, 2 it follows that one of the

\footnotetext{
* M.A., D.Phil. (Oxon); Docteur en Droit (Paris); LL.M. (Harvard); Visiting Professor of International Law and Business at Northwestern School of Law of Lewis and Clark College.

1. See the lead article, opening statement by Professor Yoram Dinstein, seven characteristic dichotomies, pp.4-5.

2. UN Doc. A/CN.4/368, Compendium of Relevant International Instruments, 1983; Yearbook of the ILC, 1986,
} 
inevitable elements is the object or victim of terrorism as a crime. Beyond the individuals or groups of persons suffering the casualties or physical injuries as the result of acts of terrorism, the target is the victim state. Terrorism is a crime directed against a state, hence it offends the conscience of mankind and the international community at the same time. Whatever the ultimate, intermediate or immediate target of terrorism, there is to be found a victim state, against which acts of terrorism are directed. The victim is primarily a state in conventional definition, 3 although of late international organizations as subjects of international law have been upgraded as possible victims of acts of terrorism along with entities such as National or People's Liberation groups or Organization or Committee. 4 Acts of terrorism committed or directed against international organizations or national liberation movements may fall within the definition of terrorism as an international crime. ${ }^{5}$

A second element which is pertinent to the questions of responsibility or liability is the author or perpetrator or subject of the international crime of terrorism. Whether or not

$\mathrm{A} / \mathrm{CN} .4 / 387$.

3. See the Convention for the Prevention and Punishment of Terrorism, adopted by the International Conference on the Repression of Terrorism on November 16, 1937, cited in U.N. Doc. A/CN.4/368 at pp.18-22, especially article 7, para. 2 .

4. Report of the Geneva seminar on the Phenomenon of Terrorism in the Contemporary World, 23-25 June 1987, by the Organization of Islamic Conference No. OIC/ISPT/REP. 1 at p.9 (Terrorism and International Law).

5. Ibid., pp.15-16 ((2) Terrorism and National Liberation Struggles). 
the applicable definition extends to crimes committed by individuals or groups of persons without the aid, assistance or participation by a state or an international organization, it is clear that it may involve an active part or role performed by a state or a group of states or an international organization or a group of international organizations. The involvement of a state may consist in the encouragement or toleration of the commission or organization in its territory or control of acts of terrorism.6 It is this second element which is relevant to the questions of responsibility which will form the first principal limb of this presentation, the other main concern of this study is centered upon the questions of complicity or degrees of participation or involvement in the planning, commission or actual consummation of terrorist acts or activities, or other supporting activities, as accessory before or after the facts of the crime of terrorism. Attention will accordingly be concentrated on these two themes, viz., responsibility and complicity.

\section{RESPONSIBILITY}

One of the initial questions that remains uppermost in the minds of those attending the colloquium on Terrorism as an International Crime relates to "responsibility." The question

6. See, e.g., Article 4(D) of the Draft Code of Offences Against the Peace and Security of Mankind, fourth report by Minister Doudou Thiam, Special Rapporteur of the International Law Commission, 1985, A/CN.4/387, 1985 Yearbook of the ILC, vol. II, Part one, pp.63-86, at pp.77-80, E. Terrorism. 
may be validly raised as to who may be held responsible for a terrorist act or an act of terrorism as an international crime.

I. THE INDIVIDUAL OFFENDER

Clearly, any person may be criminally responsible for the commission of an offense against the law of nations. No one individual is exempted or exonerated from this responsibility. There is no such rule as "the King can do no wrong" or "the Emperor is above the law" or "Caesar's wife is above suspicion."

As terrorism may easily include common crimes or ordinary offenses of murder, assassination, kidnapping, torture, etc., a person may be found guilty of such crimes under domestic law, by a national judicial authority. The same person may at the same time be personally and criminally responsible for violation of the code of offenses against the peace and security of mankind. As a matter of human rights, the accused will not be put in double jeopardy under two different systems, one domestic or national and another international. Care should be taken lest the offender escape both jurisdictions for fear of offending the rule "ne bis in idem." The problem may be one of jurisdiction, prescriptive, adjudicative or enforcement, or lack of or concurrence of any such jurisdiction or competence of one or more national authorities. The amenability of an individual person to the law of nations on terrorism is beyond controversy. Each and every man, woman or child is capable of committing an act of terrorism, the degree of liability or gravity of punishment may depend on several factors to be taken into consideration. The 
individual may be criminally liable and personally punishable, as well as civilly responsible for the pain, physical injury, death, and suffering caused to others by his terrorist acts.

II. THE OFFICIAL OR ORGAN OF A STATE OR INTERNATIONAL ORGAN IZATION

That a person is responsible individually for his or her acts of terrorism is no longer in question. But it is questionable whether responsibility persists in the event of a superior order. The defense or excuse of "respondeat superior" has application in certain legal systems, under constitutional law or administrative law or simply in accordance with the general principles of law, criminal and civil.

Whatever the extent of individual personal responsibility for acts of terrorism as an international crime in a given instance, there is also a distinct possibility that as an official, or representative or organ of a state or an international organization, the acts of terrorism in question may have been commanded by the state or international organization or committed on its behalf or at its instigation. Whatever the degree of attributability or imputability, the acts of terrorism committed by a state agent or organ of a state is clearly attributable or imputable to the state, and for which the latter is responsible. The same is true of an official or organ of an international organization. The individual is responsible both personally and as an organ or agent of the state or international organization, quite apart altogether and separate from the fact that the action or omission may invariably engage the responsibility of the state or international organization. 
The identical position is attained even if the individual official, agent, organ or representative may have exceeded his authority. In order to admit this "objective responsibility" of the state for acts committed by its officials or organs outside their competence, "they must have acted at least to all appearances as competent officials or organs, or they must have used powers or methods appropriate to their official capacity."7

III. THE STATE OR INTERNATIONAL ORGANIZATION

Should the concept of state responsibility be extended to international organizations as appears to be the rule since the Reparations case (1949), 8 Whatever is said of state responsibility in regard to a state is also equally or approximately applicable to an international organization, including a national liberation organization created by an international organization.

7. Claire Claim, France v. Mexico (1929), Verzyl, Presiding Commissioner, French-Mexican Claims Commission, 5 R.I.A.A. (United Nations Reports of International Arbitral Awards) 516. (4) Responsibility of Mexico for actions of individual military personnel, acting without orders or against the wishes of their commanding officers and independently of the needs and aims of the revolution.

8. Reparation for Injuries suffered in the service of the United Nations Case Advisory Opinion, ICJ Reports 1949, p.174. 
The next series of questions relate to the nature of the responsibility incumbent upon the state or international organization for an internationally wrongful act attributable to it, which in the case under examination is an act of terrorism as an international crime.

1. Can an Internationally Wrongful Act be Both an International Crime and an International Delict?

The classification is found in article 19 of the ILC draft on state Responsibility ${ }^{9}$ for an act of a state which constitutes a breach of an international obligation, being an internationally wrongful act. Such an act which results from the breach by a state of an international obligation so essential for the protection of fundamental interests of the international community that its breach is recognized as a crime by that community as a whole constitutes an international crime. The draft articles neither specify terrorism as an international crime, nor preclude acts of terrorism from the inexhaustive list of international obligations of essential importance to the safeguarding of the right to self-determination of people 10 and the maintenance of international peace and security.11

Paragraph 4 of draft article 19 labels all internationally wrongful acts not constituting international crimes under paragraph 2 as international delicts. Since the list in

9. See Yearbook of the ILC 1980, vol. II, Part Two, pp.30-34, at p.32.

10. Ibid., draft Article 19, (2), and (3) (b).

11. Ibid., draft Article 19, (2) and (3)(a). 
paragraph 2 is not exhaustive, there may be a host of internationally wrongful acts which may fall under either category or partially under both categories. For present purposes, however, attention is confined primarily to terrorism as an international crime. 12

2. What are the Distinguishing Features of an International Crime?

The criteria adopted in draft Article 19 point to the "seriousness of the breach," the "essential importance of the obligation breached" and "the necessity to protect the fundamental interests of the international community." The acts listed, such as, acts of aggression, colonial dominance, genocide and apartheid, are glaring examples of offenses against the peace and security of mankind. Terrorism has recently been added to such a list in the context of the draft code of offenses against the peace and security of mankind. Terrorism appears to answer all the three criteria of an international crime, having regard to the seriousness of the breach, the importance of the obligation breached and the necessity to protect the fundamental security interests and peace of mankind.

Another prerequisite might perhaps be found if the analogy of an international crime in the private law sense can be

12. For the mixed reception of draft article 19 as reflected in the debates of the Sixth Committee in 1978-1982, see Marina Spinedi: "Les Crimes Internationaux de L'Etat Dans Les Travaux de Codification de la Responsabilité des Etats Entrepris Par les Nations Unies," EUI Working Paper No. 88, Feb. 1984, pp. $42-46$. 
adopted. The attributability of an internationally wrongful act is completed without regard to the question of fault on the part of the state or international organization. As has been seen, the wrongful acts are attributable even when the officials or organs of the state act in excess of or against instructions. This is close to the theory of strict or absolute liability or liability without fault. The state is in a way vicariously responsible for practically all the acts of its officials or organs performed in that capacity even though outside the scope of their normal functions. State responsibility may be said to be thereby engaged.

To complete the components of an international crime, in private law or otherwise, the maxim: "Actus reus non facit nisi mens sit rea" is still valid. The state of mind to be imputed to the state or international organization must be one satisfying the test of the existence of a criminal intent, so as to render an internationally wrongful act a crime. By way of illustration, out of frantic panic, a fighter pilot mistook an intruding commercial aircraft as a hostile fighter-bomber and without following normal procedures for intercepting civilian aircraft shot it down without due warning in breach of international civil aviation regulations. The act is clearly an internationally wrongful act, and would also be an international crime had the pilot intended to shoot down an innocent commercial airliner. The results would be the same if the missiles were to be fired from air-to-air or from ship-to-air, or if the shot was authorized at the moment of clear and present danger. The only 
difference would be that the downing of such commercial airliner with passengers would be an internationally wrongful act without being an international crime, only if the intention imputed to the state was self-defense or self-protection even though it turned out to be a mistake of identity or otherwise. But if the intention was unmistakably to shoot down an unarmed civilian aircraft in regular commercial flight, the act of terrorism would have been accompanied by the criminal intent clearly imputable to the state or international organization, as the case may be.

3. Are the Consequences of State Responsibility for Terrorism as an International Crime the same as other Internationally Wrongful Acts?

One question that has frequently been raised is whether a state or international organization could ever be criminally responsible for an of fense constituted by acts of terrorism.13 While opposition and doubts have been voiced in the General Assembly, a good number of states appear to have accepted the possibility of a state or international organization being criminally responsible for internationally wrongful acts constituting international crimes. 14 without taking sides in this acute controversy, it is sufficient to establish that a state or international organization may be responsible under the law of state responsibility for acts of terrorism as an international crime. It makes little or no difference whether

13. Marina Spinedi, ibid., at pp.45-47.

14. Ibid., p.46, and notes $140-149$, pp.152, and notes $129-132, \mathrm{pp} \cdot 148-150$. 
the private-law terminology of "criminal liability" or the international-law term of "state responsibility" is employed. The issue is fully covered. Compensation or reparation may still be available even when wrongfulness is precluded by certain circumstances. 15

The next logical step is to examine the consequences of ... state responsibility or the secondary, as opposed to primary rules of obligations flowing from its breach of the primary rules requiring abstention from acts of terrorism. The consequences of state responsibility in respect of an international crime would seem not to differ whether we call it criminal liability by name or simply state responsibility. Nor does it make any difference in effect whether the same set of facts or circumstances are characterized as an international crime or an international delict.

IV. LEGAL CONSEQUENCES OF AN INTERNATIONAL CRIME COMMITTED BY A STATE OR AN INTERNATIONAL ORGANIZATION.

Independently of the nature of the responsibility encumbent on the state, whether or not it is designated as criminal, certain legal consequences flow from the breach of its primary obligation not to commit an act of terrorism as an international crime. The problem of definition of the international crime of terrorism has been discussed elsewhere by other confrères at the Colloquium. The primary rules regarding components of acts of

15. See, in particular, draft article 35 of the draft articles on State Responsibility, cited in note 9 above. 
terrorism as an international crime, including the wrongful act and the criminal intent, has also been briefly mentioned. We may now proceed to consider the legal consequences of state responsibility for terrorism as an international crime.

Following an interesting study made by the International Law Commission in Part I of the draft Articles on State Responsibility, certain principles appear to have emerged, which may be stated in outline in more tangible terms.

\section{(a) The Three Parameters}

On close inspection, the consequences in terms of rights and obligations, as secondary rules, may consist in three different parameters, namely:

(i) The new obligations of the state which has committed an international crime of terrorism;

(ii) the new rights of the injured state victim of the acts of terrorism characterized as an international crime; and

(iii) the rights and obligations of third states or third organizations.

It is permissible to examine the secondary rules or legal consequences of state responsibility in each of these parameters.

(b) The First Parameter, the state Committing an

Obligations on the part of the state responsible for acts

15 bis See, e.g., Document A/CN.4/342 and Add. 1-4, Yearbook of the ILC 1981, vol. II, Part one, pp.71-101, at pp.82 et seg. 
of terrorism characterized as an international crime include the following steps:

(i) Ex nunc or an obligation to cease all wrongful activities or acts of terrorism, or an obligation to desist from further encouragement or assistance furnished to perpetrate acts of terrorism as an international crime. This obligation ex nunc only applies to continuing wrong or violation, such as intrusion of territorial air space which may be stopped by withdrawal from the air space. On the other hand, if the acts of terrorism consist in a oneshot or two-shots affair, then it is an accomplished act which can no longer be stopped.

(ii) Ex tunc or an obligation to reestablish the situation which would have existed if the breach had not been committed, where restitution is still practicable. Restitutio in integrum would be required of the state which has committed an internationally wrongful act. But the nature of the act does not always permit restitution. If, for instance, the aircraft was shot and disintegrated in mid-air while the bodies of the passengers killed were scattered over the ocean, no resuscitation or reintegration would seem possible. In such event, there would at least be an obligation to pay the injured state a sum of money corresponding to the loss suffered and not yet repaired.

(iii) Ex ante or an obligation to give satisfaction in the form of formal apologies for the breach, a formal reconfirmation of the obligation breached, or the declaration to the effect that measures would be taken in order to prevent recurrence of similar breaches. Thus, an arrangement was set up to monitor flights of commercial airlines in the polar or northern routes to prevent the repetition of the downing of a civilian aircraft in regular commercial flight. An undertaking to adopt appropriate measures to prevent recurrence of such terrorizing acts would be in order.

(c) The Second Parameter, the Injured State, Victim of Terrorism as an International Crime

The injured state may demand fulfillment of, or compliance with, secondary obligations, ex nunc, ex tunc and ex ante from the state whose act was internationally wrongful. The exercise of corresponding rights would be permissible upon giving due notification of the breach. The injured state may resort to 
counter-measures to compel compliance with its demand or else to suspend performance of its obligation under a bilateral treaty or multilateral instrument which may yield satisfactory results. Legitimate sanctions may be imposed to induce compliance, such as boycotting or rupture of diplomatic relations or refusal to extend recognition or withdrawal of recognition of the regime or state engaging in acts of terrorism. In particular, the injured state is entitled to

(i) cessation of the wrongful act if it is of a continuing nature, or abatement of continuing injury or damage;

(ii) payment of appropriate compensation or reparation, equivalent to the loss suffered; and

(iii) satisfaction by an assurance that similar wrongful acts would be prevented in future by adopting preventive or precautionary measures or more effective monitoring or warning system.16

\section{(d) The Third Parameter, Third State or Every Other state}

It is appropriate to complete the current analysis by a brief examination of the contents of the third parameter, viz., obligations entailed by an international crime, such as terrorism, for every other state. Third states or every other state may be said to be under the following obligations:

(i) not to recognize as legal the situation created by or brought about by acts of terrorism, whether by taking of hostages or assassinations or tortures;

(ii) not to render aid or assistance to the state or organization which has committed such crime; and

(iii) to join other states in affording mutual assistance in carrying out the obligations flowing from the acts of

16. Ibid., pp.91-101. 
terrorism. An international body, consisting of member states, may adopt a resolution penalizing such criminal acts or imposing sanctions on the recalcitrant state, by expulsion from the organization or curtailment of its voting rights or other legitimate sanctions proportional to induce compliance and prevention of future repetitions. Measures envisaged under this rubric may be adopted in conformity with the procedures embodied in the United Nations Charter with respect to the maintenance of international peace and security, and other multilateral treaties. 1

\section{COMPL ICITY}

An analysis will be attempted in Part B of this paper to comprehend the different methods and degrees of involvement of a state in terrorist acts which would engage state responsibility. Complicity may take different forms.

\section{STATE TERRORISM}

This is a direct involvement. When a state or its officials or organs undertake or organize terrorist acts directed against another state. The state committing terrorism is the author of the international crime of terrorism. It is the principal perpetrator of the crime, as if the button was pushed by the state itself to destroy a peaceful civilian aircraft in regular commercial flight deliberately to inflict loss of lives on the passengers.

The state may do the planning, organization, or training of terrorists to undertake terrorist activities against another

17. See Yearbook of the ILC 1985, vol. II, Part one (Sixth Report by Professor Riphagen, A/CCN4.1389) at pp.13-14. See Dinstein, in note $7, \mathrm{pp} .14$. 
state. This could be done singly, or in concert with other states or international organizations. Equality of partnership or joint-venture in the crime of terrorism may constitute a form of complicity, beyond conspiracy as it takes the form of actual participation. All participating states or organizations act as principals or partners in crime. The division of labor may vary from each act of terrorism, such as terrorizing a village, or explosion of a school bus, by agents or organs of a state or more than one state or organization.

II. STATE-ASSISTED OR STATE-ENCOURAGED TERRORISM

Assisting or encouraging the commission of terrorist acts engages the responsibility of the state for the international crime as a form of complicity. Active participation is not needed. Their assistance by giving information, lending facilities, harboring terrorists from neighboring countries, etc., may be sufficient to create responsibility of the state for the act of terrorism. Thus, the 1937 Geneva Convention on the Suppression of Terrorism" 18 reaffirms "the principle of international law in virtue of which it is the duty of every State to refrain from any act designed to encourage terrorist activities directed against another state and to prevent the acts in which such activities take shape." This obligation imposes on every state not only the duty to refrain from assisting or

18. See article 7 para 7 of the Convention, see compendium of Relevant International Instruments, U.N. Doc. A/CN.4/368, at p. 18 . 
encouraging acts of terrorism, but also the duty to prevent and punish activities of this nature, and also to collaborate with other states for this purpose. Failure to perform this duty engages state responsibility for the resultant acts of terrorism.

\section{II . STATE-TOLERATED TERRORISM}

The toleration of "activities organized for the purpose of carrying out terrorist acts in another state" amounts to a crime against peace and security of mankind as envisaged in the report of Minister Doudou Thiam 19 to the International Law Commission. The imputation of knowledge and therefore responsibility to the state for whatever internationally wrongful acts conducted on its territory within its own border is not unwarranted. This is consistent with the duty to warn, to abate and to prevent harm as indicated in the Corfu Channel Case 1949.20 Allowance, permission, acquiescence or toleration of terrorist activities known to be directed against another state clearly entails the responsibility of the territorial state. A state is under an obligation to prevent the training, organization or preparation of such activities within its territory.

It is conceivable in exceptional circumstances that the territorial state may be aware of the activities being conducted on its soil and remain yet powerless to prevent them. The obligation not to tolerate may in part be fulfilled by

19. Report of the ILC 1986, Yearbook, vol. II, Part two, Article 11(4)D.

20. ICJ Reports, 1949, p.4, at p.22. 
collaboration with an international authority or other states to avert the danger resulting from terrorist activities or to inform other states or international body of the situation.

IV. MANUFACTURE, PROCURING, OR SUPPLYING OF ARMS, AMMUNITION, EXPLOSIVES OR HARMFUL SUBSTANCES WITH A VIEW TO THE COMMISSION OF A TERRORIST ACT.

The act of terrorism need not be the ultimate destruction or seizure of victims or targets, but may comprehend other parts of activities contributing to the materialization or final consummation of a criminal act of terrorism. Thus, as early as 1937 an international convention lists as prohibited "the manufacture, obtaining possession, or supplying of arms, ammunitions, explosives, or harmful substances with a view to the commission in any country whatsoever of an offence" designated as acts of terrorism. It is the purpose for which arms and ammunitions are procured, obtained, manufactured or supplied that makes it an internationally wrongful act. This is the initial part of a series of acts composing the crime of terrorism. It is the knowledge or object of the supply of such harmful substance that provides the linkage or complicity with the crime of terrorism itself, for which the state as accomplice would be held responsible.

\section{CONCLUSION}

The lesson to be learned from the preceding analysis of state responsibility and state complicity in the context of terrorism as an international crime is that a collective and 
unified response to international terrorism is one effective means to prevent or discourage the staging of terrorism. Avowedly, states of different size, structure, ideology and stage of economic development have openly opposed acts of terrorism in every form or manifestation. To implement this opposition, states could collaborate more closely with the international community by becoming parties or adhering to the international instruments designed to prevent, suppress and punish acts of terrorism.21 By so promoting measures of prevention and expanding the scope of enforcement of legitimate sanctions against terrorism, the rate of such international crimes could be lowered, if not immediately suppressed. The colloquium is finding the right path and should be encouraged to continue its search for ways and means to combat terrorist activities which threaten the peace and tranquility of mankind.

Sompong Sucharitkul

21. See, e.g., The Tokyo Convention, on offences and Certain Other Acts Committed on Board Aircraft, September 14 , 1963, 704 UNTS. 219; The Hague (Hijacking) Convention, for the Suppression of Unlawful Seizure of Aircraft, December 16, 1970, 22 U.S.T. 1641, 10 I.L.M. 133; Montreal (Sabotage) Convention, for the Suppression of Unlawful Acts Against the Safety of Civil Aviation, September 23, 1971, 24 U.S.T. 564, 10 I.L.M. 1151; International Convention Against the Taking of Hostages, December 17,1979 U.N. DoC. A/34/819, 74 A.J.I.L. 277 (1980); Convention on the Prevention and Punishment of Crimes Against Internationally Protected Persons, including Diplomatic Agents, December 14, 1973, 28 U.S.T. 1975, 13 I.L.M. 41; European Convention on the Suppression of Terrorism, November 10, 1976, T.S. No. 90, 15 I.L.M. 1272; and recently, Convention for the Suppression of Unlawful Acts against the safety of Maritime Navigation, March 10, 1988, Rome, 27 I.L.M. 668 (1988) and Protocol. 
- 